\title{
Temperature responses of ribulose bisphosphate carboxylase and photosynthetic capacity in arctic and tropical phytoplankton
}

\author{
John Clegg Smith \& Trevor Platt
}

Marine Ecology Laboratory, Bedford Institute of Oceanography, P. O. Box 1006, Dartmouth, Nova Scotia, Canada B2Y 4A2

\begin{abstract}
When assayed near respective in situ temperatures, ribulose bisphosphate carboxylase (RuBPC) exhibits a greater response to increasing temperature in arctic than in tropical phytoplankton. This was also true when the Arrhenius activation energy $\left(E_{a}\right)$ was compared for a range of intermediate temperatures. This difference in temperature response and $E_{a}$ for RuBPC is consistent with the temperature response of photosynthetic capacity, but is contrary to the general observation that coldenvironment ectotherms (organisms whose internal temperature conforms to that of the environment) have physiological processes with lower $E_{a}$ 's. Analysis suggests that the genotypic adaptation of qualititative enzyme temperature responses in marine phytoplankton is related to the vertical structure of the environment and to a suite of variables of which temperature is only one. Quantitatively, however, arctic phytoplankton do not appear to adapt to cold by increasing RuBPC levels per unit pigment biomass.
\end{abstract}

\section{INTRODUCTION}

The chemical reactions of metabolism in ectotherms (organisms whose internal temperature conforms to that of the environment) do not operate with the same efficiency at all latitudes. Comparisons of the efficiencies of reactions mediated by homologous enzymes from polar and tropical ectotherms generally show that the polar form is a more efficient catalyst and this may be a characteristic, genotypic alteration of adaptive significance to life in the cold (Hochachka \& Somero 1971, 1973; Low et al. 1973, Johnston \& Goldspink 1975, Horwitz \& Hettinger 1979). Ribulose-1,5-bisphosphate carboxylase (RuBPC, E.C.4.1.1.39) is an important enzyme, diagnostic of the autotrophic mode of life (Whittenbury \& Kelly 1977) and the catalyst of the primary carboxylation process and possible ratecontrolling step of photosynthesis (Bassham 1971). The principal objective of this study was to compare the temperature responses of the RuBPC's of natural polar and tropical marine phytoplankton assemblages as measured by the apparent Arrhenius activation energy, $E_{a}$. We found that in contrast to the standard pattern described above, $E_{a}$ for RuBPC was significantly higher (indicating a lower catalytic efficiency) for polar than for tropical phytoplankton. A further aim of this research was to seek a possible explanation for this unexpected finding by examining the structural characteristics of the physical environments typically inhabited by these 2 groups of organisms.

\section{METHODS}

Sampling locations and methods. Observations on RuBPC activity and photosynthetic capacity were made on samples gathered on oceanographic cruises to the eastern Canadian Arctic (Jul-Aug 1980, Irwin et al. 1983b; Aug-Sep 1981, Irwin et al. 1983a), to the eastern tropical Pacific and Costa Rica Dome regions (Feb-A.pr 1981, Longhurst 1981) and to the subtropical Atlantic west of the Azores (May-Jun 1981, Irwin et al. 1983c).

Continuous profiles of temperature were obtained using a Guildline model 8770 portable CTD. Samples were collected using a submersible pump sampler or by Niskin bottle; equivalent samples were obtained by either method (Herman et al, 1984). Phytoplankton cells for physiological studies were collected from replicate subsamples by gentle vacuum filtration onto 
Whatman GF/F glass fiber filters. Subsamples for chlorophyll determinations were filtered immediately; those for RuBPC measurements were filtered prior to an incubation period (as required by the assay method), while those subsamples for photosynthetic capacity determinations were filtered following an incubation period in a light-gradient incubator. In some cases, the population was divided according to cell size. The fractionation procedure consisted of first passing a sample through a $1 \mu \mathrm{m}$ pore diameter Nuclepore screen and then passing the filtrate through a GF/ $F$ filter; we refer to the retentate on the GF/F filter as the $<1 \mu \mathrm{m}$ or picoplankton fraction (the retentate on a $\mathrm{GF} / \mathrm{F}$ from an unfractionated sample being referred to as the whole sample). Although the manufacturer claims that $\mathrm{GF} / \mathrm{F}$ filters retain particles down to $0.7 \mu \mathrm{m}$ in diameter, our experience in many marine environments has been that these filters are roughly equivalent to $0.4 \mu \mathrm{m}$ pore diameter Nuclepore screens. This $<1 \mu \mathrm{m}$ fraction differs somewhat from the definition of picoplankton ( 2 to $0.2 \mu \mathrm{m}$ fraction) given by Sieburth et al. (1978) but has proven operationally convenient in dealing with the 100 to $500 \mathrm{ml}$ sample volumes typically used in physiological studies. It was particularly important not to fractionate samples for photosynthetic capacity determinations prior to incubation since we have shown (Smith et al. 1985) that this selectively disrupts certain photosythetic processes; the enzyme and chlorophyll determinations do not appear to be affected, however.

ChlorophyII, photosynthetic capacity and RuBPC activity. Chlorophyll a was measured by the fluorometric technique of Yentsch \& Menzel (1963) as modified by Holm-Hansen et al. (1965). Samples were extracted overnight in $85 \%$ acetone at $0^{\circ} \mathrm{C}$ in the dark. The fluorometer (Turner, red sensitive door) was calibrated using acetone extracts of pure chlorophyll a (Sigma Chemical Co.).

Photosynthetic capacity (assimilation number or $\mathrm{P}_{m}^{b}$ : the light-saturated photosynthetic rate, $P_{m}$, normalized to chlorophyll biomass, b) was measured at 4 incubation temperatures in temperature-controlled light gradient incubators as described by Irwin et al. (1982); the data were analyzed using the equation of Platt et al, (1980) and the fitting procedures described by Gallegos \& Platt (1981).

Assay methods for RuBPC are described in Smith et al. $(1983,1985)$ and Li et al. (1984). RuBPC activity was measured radiometrically by determining the rate of RuBP-dependent fixation of ${ }^{14} \mathrm{CO}_{2}$ into acid stable products in a quasi in vivo assay utilizing cells permeabilized by treatment with glycerol (Syrett 1973) and L-a-lysophosphatidylcholine (Miller et al. 1978, 1979, Castellot et al. 1979). The method is otherwise a modification of that of Mukerji \& Morris (1976). Similar permeable cell assays for RuBPC are commonly used in other laboratories (e.g. Tabita et al. 1978, Storro \& McFadden 1983).

RuBPC assays were carried out at 7 different temperatures in darkened, temperature-controlled incubators. Four experimental and 2 blank (no RuBP) replicates were determined for each temperature. Blank values were not temperature dependent and appeared to result from acid stable, mainly organic impurities in the ${ }^{14} \mathrm{C}$ stock solutions. These impurities did not affect the enzymatic reaction, however. The average value for blanks, for particular lots of ${ }^{14} \mathrm{C}$, was subtracted from experimental values. Assays were incubated for approximately $1 \mathrm{~h} ;{ }^{14} \mathrm{C}$ uptake was linear for more than $2 \mathrm{~h}$ and was linearly dependent on biomass.

\section{RESULTS}

Arrhenius plots of logarithm of RuBPC activity versus reciprocal of absolute temperature are given for typical arctic and tropical stations in Fig. 1A \& B respectively. It is clear for the arctic sample (Fig. 1A), that RuBPC activity approximates an exponential function of temperature (i.e. the Arrhenius plot appears linear) over nearly the entire range of experimental temperatures, with the possible exception of the highest incubation temperature $\left(25^{\circ} \mathrm{C}\right.$, leftmost group of points, $10^{3} / \mathrm{T} \simeq 3.35 \mathrm{~K}^{-1}$ ). That is, RuBPC activity increased exponentially with increasing temperature up to more than $20 \mathrm{C}^{\circ}$ above the in situ (sample) temperature $\left(1.4^{\circ} \mathrm{C}\right.$, Station X228, Table 1$)$. In contrast, RuBPC activity from the tropical station (Fig. 1B) which had a sample temperature of $25.9^{\circ} \mathrm{C}$ (Station T962, Table 1) appeared to be an exponential function of temperature only up to about $2 \mathrm{C}^{\circ}$ above $\left(10^{3} / \mathrm{T}=3.329\right.$ $\mathrm{K}^{-1}$ ) the in situ temperature. Above this temperature, RuBPC activity did not increase and began to decline at about $30^{\circ} \mathrm{C}$

The values of $E_{a}$ given in Fig. $1 \mathrm{~A} \& \mathrm{~B}$ and Table 1 were calculated using all data for arctic samples, but, for tropical stations, only data from the linear region of the Arrhenius plot were used. The extent of this linear region was determined subjectively but included the replicate set from nearest the in situ temperature and that from the next higher experimental temperature. The same procedure was used in determining $E_{a}$ 's for the other samples in Table 1. Thus, $E_{a}$ 's for both sets of stations were calculated for ranges of temperature over which the Arrhenius plots appeared to be linear, which included the respective in situ temperatures, and which, moreover, overlapped each other. We suggest that these conditions must be met if a valid comparison is to be made between the 2 sets of stations by using a quantitative measure such as $\mathrm{E}_{\mathrm{a}}$ for RuBPC. By these 

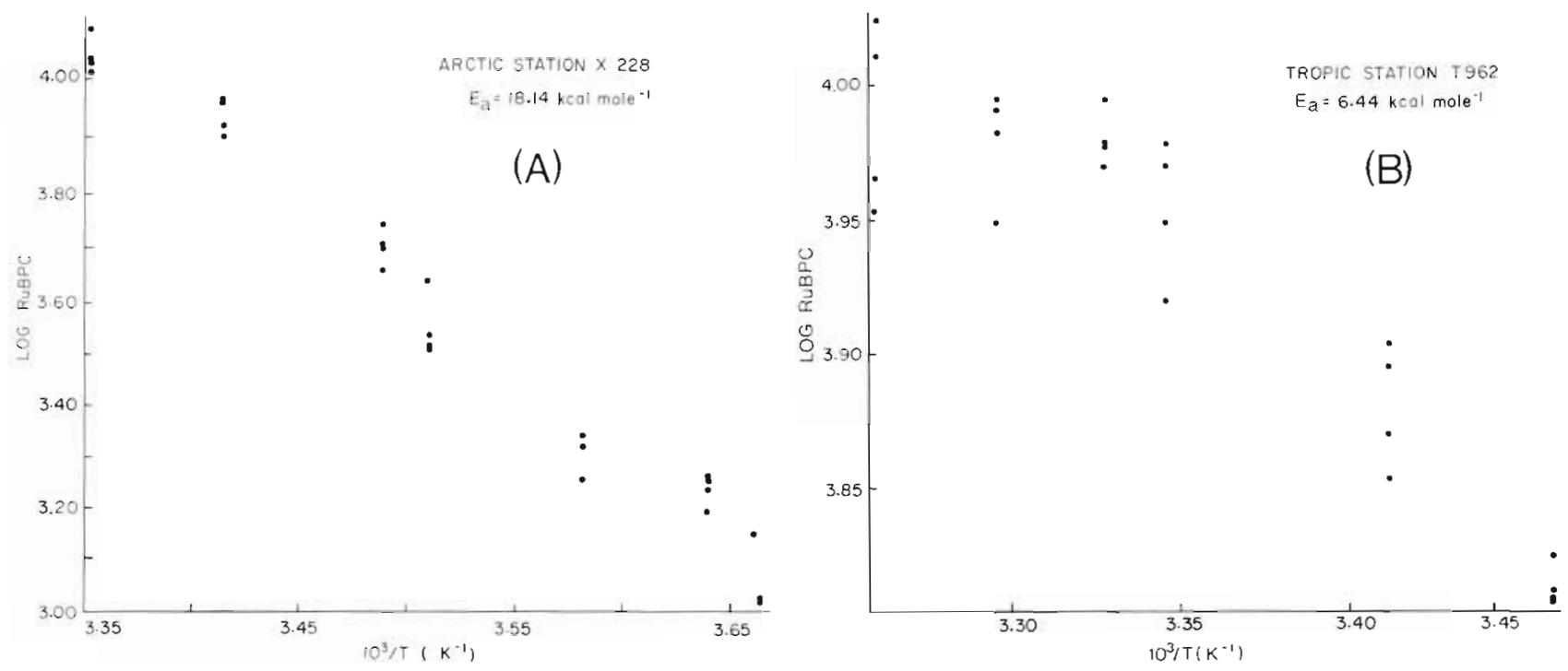

Fig. 1. Arrhenius plots of logarithm RuBPC activity (untransformed units, dpm $1^{-1} \mathrm{~h}^{-1}$ ) versus $10^{3}$ times reciprocal absolute temperature $\left(\mathrm{K}^{-1}\right)$ for typical arctic $(\mathrm{A})$ and tropical $(B)$ stations. $E_{\mathrm{a}}$ values were calculated using all experimental points for arctic sample, but utilizing only the 4 lowest temperatures (linear region of Arrhenius plot) for tropical sample

criteria then, the mean value of $E_{a}$ for RuBPC for all arctic stations is significantly higher ( $t$-test, $P<0.01$ ) than the mean $E_{a}$ for the tropical station set (Table 1).

It is also apparent that the Arrhenius activation energy $\left(E_{a}\right)$ values do not appear to photoadapt; that is, within the arctic and tropical sampling regions, $E_{a}$ 's are not related to sampling depth or to sampling depth with respect to the pycnocline (Table 1) but seem only to depend on the geographical region whence the sample came. Additionally, the temperature response $\left(E_{\mathrm{a}}\right)$ of RuBPC in tropical picoplankton (Li et al. 1983, Platt et al. 1983) (Table 1, Stations T962 \& T007, $<1 \mu \mathrm{m}$ fraction) was similar to that for the whole sample.

The effect of incubation temperature on the assimilation numbers $\left(\mathrm{P}_{\mathrm{m}}^{\mathrm{b}}\right)$ for 2 sub-tropical stations (a whole sample and a picoplankton fraction) near the Azores, a

Table 1. General sampling data, $\mathrm{E}_{\mathrm{\alpha}}$ for RuBPC, and chlorophyll-normalized RuBPC activities at both $20^{\circ} \mathrm{C}$ and in situ temperature. $Z_{p}$ : sample depth with respect to the pycnocline $(1$, sample from mixed layer; 2 , sample from within density gradient; 3, sample from below density gradient); $\mathrm{T}$ : sample temperature $\left({ }^{\circ} \mathrm{C}\right)$; $\mathrm{Z}$ : sample depth (m); $\mathrm{E}_{\mathrm{a}}$ : Arrhenius activation energy (kcal mole ${ }^{-1}$ ); CHLA: sample chlorophyll a concentration ( $\mu \mathrm{g}^{-1}$ ); RuBPC ${ }^{b}$ chlorophyll a-normalized RuBPC activity (dpm [CHLA] ${ }^{-1} \mathrm{~h}^{-1}$ )

\begin{tabular}{|c|c|c|c|c|c|c|c|c|}
\hline \multirow[b]{2}{*}{ Station } & \multirow[b]{2}{*}{ Position } & \multirow[b]{2}{*}{$z_{p}$} & \multirow[b]{2}{*}{$\mathrm{T}$} & \multirow[b]{2}{*}{$\mathrm{Z}$} & \multirow[b]{2}{*}{$E_{a} \pm S E$} & \multirow[b]{2}{*}{ CHLA } & \multicolumn{2}{|c|}{$\mathrm{RuBPC}^{\mathrm{b}}$} \\
\hline & & & & & & & $20^{\circ} \mathrm{C}$ & in situ \\
\hline \multicolumn{9}{|l|}{ Arctic } \\
\hline M 050 & $74^{\circ} 13^{\prime} \mathrm{N}, 81^{\circ} 48^{\prime} \mathrm{W}$ & 2 & 2.0 & 11 & $16.91 \pm 0.49$ & 2.36 & 2958 & 449 \\
\hline M 057 & $75^{\circ} 47^{\prime} \mathrm{N}, 79^{\circ} 32^{\prime} \mathrm{W}$ & 2 & 0.2 & 10 & $17.20 \pm 1.50$ & - & - & - \\
\hline$\times 228$ & $69^{\circ} 21^{\prime} \mathrm{N}, 80^{\circ} 34^{\prime} \mathrm{W}$ & 3 & 1.4 & 40 & $18.14 \pm 0.62$ & 0.78 & 10050 & 1245 \\
\hline$\times 280$ & $69^{\circ} 26^{\prime} \mathrm{N}, 80^{\circ} 47^{\prime} \mathrm{W}$ & 3 & 1.3 & 40 & $19.06 \pm 0.64$ & 0.48 & 21200 & 2335 \\
\hline$\times 361$ & $68^{\circ} 23^{\prime} \mathrm{N}, 80^{\circ} 07^{\prime} \mathrm{W}$ & 1 & 2.1 & 2 & $18.06 \pm 1.32$ & 0.84 & 29140 & 3982 \\
\hline \multicolumn{9}{|l|}{ Tropical } \\
\hline D 711 & $07^{\circ} 20^{\prime} \mathrm{N}, 83^{\circ} 25^{\prime} \mathrm{W}$ & 2 & 21.5 & 38 & $9.50 \pm 0.72$ & 0.88 & 9344 & 10618 \\
\hline D 727 & $08^{\circ} 09^{\prime} \mathrm{N}, 87^{\circ} 48^{\prime} \mathrm{W}$ & 2 & 25.2 & 25 & $12.88 \pm 0.84$ & 0.47 & 18150 & 26751 \\
\hline D 765 & $09^{\circ} 30^{\prime} \mathrm{N}, 89^{\circ} 35^{\prime} \mathrm{W}$ & 3 & 17.0 & 23 & $11.07 \pm 0.77$ & 0.87 & 4847 & 3990 \\
\hline D 827 & $11^{\circ} 50^{\prime} \mathrm{N}, 89^{\circ} 35^{\prime} \mathrm{W}$ & 1 & 26.5 & 0 & $9.98 \pm 0.53$ & 1.15 & 23950 & 34714 \\
\hline D 873 & $09^{\circ} 23^{\prime} \mathrm{N}, 89^{\circ} 30^{\prime} \mathrm{W}$ & 1 & 25.2 & 10 & $9.97 \pm 0.42$ & 1.47 & 28830 & 38922 \\
\hline T 962, Whole & $09^{\circ} 39^{\prime} \mathrm{N}, 93^{\circ} 44^{\prime} \mathrm{W}$ & 2 & 25.9 & 42 & $6.44 \pm 0.42$ & 1.29 & 5526 & 6886 \\
\hline $\mathrm{T} 962,<1 \mu \mathrm{m}$ & & & & & $7.48 \pm 0.78$ & 0.75 & 7515 & 9715 \\
\hline T 007. Whole & $09^{\circ} 46^{\prime} \mathrm{N}, 93^{\circ} 44^{\prime} \mathrm{W}$ & 2 & 24.4 & 43 & $9.61 \pm 1.08$ & 0.71 & 6570 & 8382 \\
\hline $\mathrm{T} 007,<1 \mu \mathrm{m}$ & & & & & $4.09 \pm 0.56$ & 0.21 & 13702 & 15162 \\
\hline
\end{tabular}


subarctic Labrador Shelf sample, and a north Baffin Bay arctic sample are plotted in Fig. 2A, B, C \& D respectively. Although too few data are available to permit the presentation of Arrhenius plots and the computation of $E_{a}$ 's, it is clear that the $P_{m}^{b}$ results are

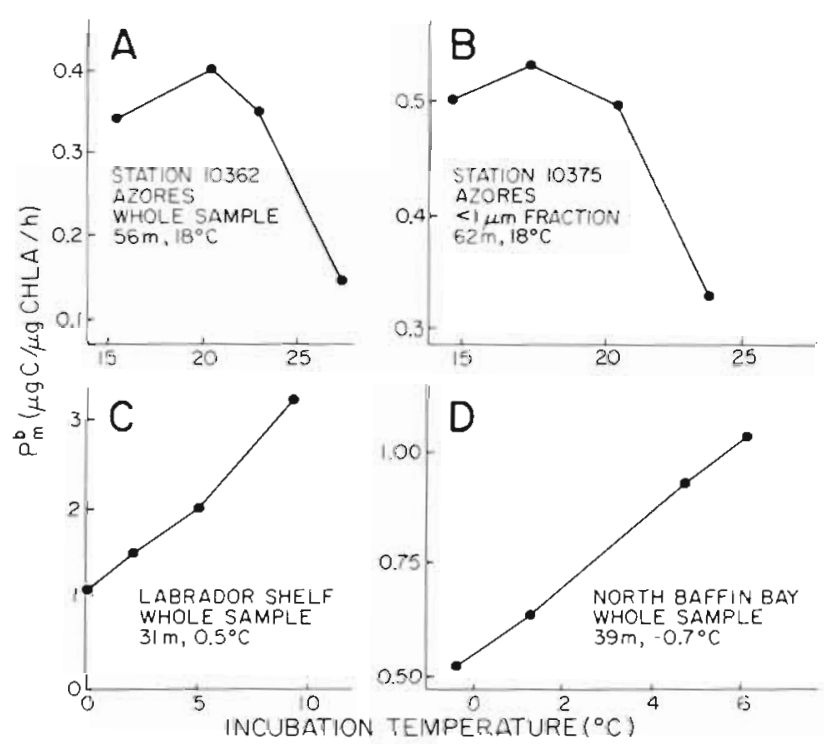

Fig. 2. Chlorophyll-normalized, light-saturated phytosynthetic rate, $\mathrm{P}_{\mathrm{m}}^{\mathrm{b}}$ versus incubation temperature for stations near the Azores (A, B), from the Labrador Shelf (C) and from Baffin Bay (D). Note similarity of temperature response of photosynthesis for whole sample (A) and for picoplankton fraction (B)

qualitatively comparable to those for RuBPC. That is, $\mathrm{P}_{\mathrm{m}}^{\mathrm{b}} \mathrm{s}$ for both the whole sample and picoplankton fractions from the Azores stations are inhibited at temperatures only slightly above in in situ whereas there are no indications of this inhibition in either the subarctic or arctic samples. It is also clear from an inspection of Fig. $2 \mathrm{~A}$ to $\mathrm{D}$ that $\mathrm{P}_{\mathrm{m}}^{\mathrm{b}}$ in the arctic samples approximately doubles for a $5 \mathrm{C}^{\circ}$ increase in temperature whereas this increase (in the non-inhibitory range) is much less for Azores samples. As was the case for RuBPC, $\mathrm{P}_{\mathrm{m}}^{\mathrm{b}}$ varied with temperature in a similar way for picoplankton (Fig. 2B) as for larger phytoplankton (Fig. 2A).

\section{DISCUSSION}

The results show that both RuBPC activity and $\mathrm{P}_{\mathrm{m}}^{\mathrm{b}}$ increase more rapidly with temperature for arctic than for tropical phytoplankton samples. Li et al. (1984) have also shown that RuBPC and $\mathrm{P}_{\mathrm{m}}^{\mathrm{b}}$ for phytoplankton from arctic and subarctic stations have similar high and nearly identical $E_{a}$ 's. The phytoplankton population at the tropical stations reported here consisted largely of cyanobacteria (Li et al. 1983, Platt et al. 1983) and Paerl et al. (1983) and Paerl (pers. comm.) reported very low $Q_{10}$ 's for photosynthetic potential in these organisms $\left(Q_{10}\right.$ for $P_{m}^{b}$ was 1.26 for Microcystis aeruginosa and 1.34 for Anabaena oscillarioides) although $Q_{10}$ 's for growth may be more 'normal' in other cyanobacteria $(\approx 2.0$ for Oscillatoria redekei and $O$. agardhii [Foy 1983]). These considerations plus the fact that RuBPC and $\mathrm{P}_{m}^{b}$ in this study were determined by completely different methods make it extremely improbable that the present results are attributable to some experimental anomaly.

Our interpretation of the RuBPC results is dependent on the set of criteria we proposed above. It is clear, however, that in the vicinity of the respective in situ temperatures, the response of RuBPC to a change in temperature is much greater for arctic than for tropical phytoplankton. At temperatures only slightly above in situ, moreover, the temperature response of RuBPC for tropical phytoplankton is further diminished relative to arctic phytoplankton. The fact that the linear regions of the Arrhenius plots which include the respective in situ temperatures overlap at intermediate temperatures (Fig. 1A, B), indicates that the RuBPC molecule functions differently in arctic as opposed to tropical phytoplankton. We suppose the basis for this adaptation to be genotypic but have not attempted to demonstrate this directly. This adaptation need not involve the RuBPC molecule directly but could result from an alteration of the lipid composition of the relevant intracellular membranes (Raison 1980).

Accepting this interpretation for the moment, these observed differences in a metabolically-important enzyme (RuBPC) and in photosynthetic potential $\left(\mathrm{P}_{\mathrm{m}}^{\mathrm{b}}\right)$ of pelagic zone phytoplankton assemblages are opposite to those commonly exhibited by the enzymes and physiological processes of ectotherms from contrasting thermal environments. What might be the ecological significance and thermodynamic implications of such adaptations?

In the arctic in summer, the water column is characteristically well-stratified, with a sharp, shallow pycnocline and a shallow euphotic zone. This may be contrasted to the open tropical ocean with a deep mixed layer, a broader, deeper pycnocline and a deeper euphotic zone due to the lesser extinction of light in the water column. Thus, phytoplankton cells could experience greater relative changes in temperature and irradiance in the arctic than in the tropics during an equal vertical excursion. Arctic phytoplankton assemblages are both light- and temperaturelimited (Harrison et al. 1982) while the growth of openocean, tropical phytoplankton is more likely to be limited by nutrient availability (Eppley et al. 1977). The arctic environment might, therefore, be best exploited by light-dependent metabolic processes that 
are temperature-sensitive (i.e. with a high $E_{a}$ ). If the growth of tropical phytoplankton is typically not limited by temperature or irradiance, there is probably no advantage in having light-related processes with high $E_{a}$ 's. It is noteworthy that 2 other carboxylating enzymes we studied (phosphoenolpyruvate [PEP] carboxylase and PEP carboxykinase), which are not directly linked to the light reactions of photosynthesis, possess low $E_{a}^{\prime}$ 's in both arctic (Li et al. 1984) and tropics (unpubl., this laboratory).

Related to these suggestions is the finding of an anomalous Arrhenius plot for the sample from Station D765, collected from below the pycnocline at the Costa Rica Dome (Fig. 3). Environmental conditions were

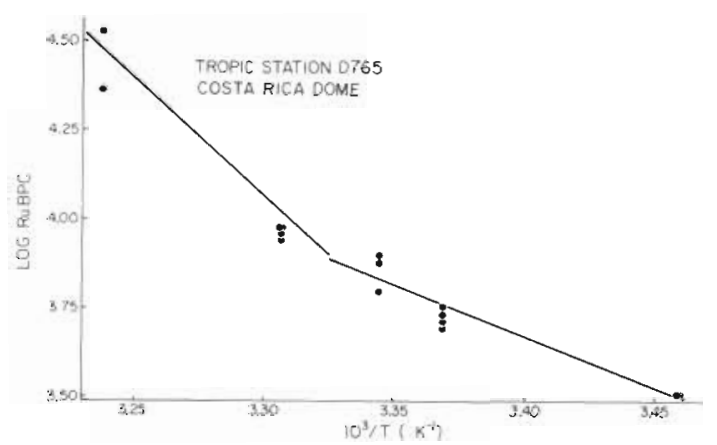

Fig. 3. Arrhenius plot of logarithm RuBPC activity (untransformed units, dpm $1^{-1} h^{-1}$ ) versus $10^{3}$ times reciprocal absolute temperature $\left(\mathrm{K}^{-1}\right)$ for a sample from below the pycnocline at the Costa Rica Dome. Lines illustrating the 'break' in the Arrhenius plot were added subjectively

unusual for an open-ocean, tropical station in that shoaling of the isotherms led to a combination of relatively low temperature and high irradiance. There appears (subjectively) to be a break in the Arrhenius plot a few degrees above the in situ temperature, but the break is in the direction opposite to the usual finding (Berry \& Raison 1981), with $E_{a}$ increasing at higher temperatures and no obvious inhibition. This counter-example shows that in the appropriate conditions (upwelling), phytoplankton from a tropical ocean station can respond like arctic phytoplankton. It seems that the environmental gradient of temperature in relation to the irrediance field exerts a stronger control on the enzyme adaptation than temperature per se.

Two further points arise from the data of Table 1. First, chlorophyll-normalized RuBPC activity (RuBPC ${ }^{b}$ ) is strongly influenced by irradiance. Thus, both arctic and tropical samples from the surface mixed layer (high irradiance) have greater RuBPC ${ }^{\mathrm{b}}$ (chlorophyllnormalized RuBPC) values than low irradiance samples from within or below the density gradient and, hence, isolated from the surface. Presumably this is due to a lower photosynthetic unit size for surface samples and may be associated with an increase in both the density of photosynthetic units and photosynthetic efficiency (Smith et al. 1983). Second, when compared at the intermediate temperature of $20^{\circ} \mathrm{C}$, RuBPC $^{b}$ from the arctic, mixed-layer sample is similar to the tropical, mixed-layer samples, and this is also true when the deeper samples are compared. At in situ temperatures, however, the difference between arctic and tropical samples in $\mathrm{R}_{\mathrm{BPC}} \mathrm{C}^{\mathrm{b}}$ levels is readily apparent. This indicates that although RuBPC is qualitatively different (different $E_{a}$ 's) for these contrasting thermal environments, its capacity (activity per unit pigment biomass) is conservative. Consequently, arctic phytoplankton do not adapt to the cold environment by having higher enzyme concentrations

We expected to find that arctic phytoplankton would have lower or similar $E_{a}$ 's for RuBPC and photosynthesis relative to tropical species. That they have higher values seems to be attributable to the absolute temperature being less important than the temperature structure of the water column in relation to irradiance, the limiting factors for growth, and the exploitative strategy of the characteristic species. Indeed, our results can be understood in the context that arctic phytoplankton species are basically opportunistic, having a primary carboxylating metabolism that is energetically inefficient (high $\mathrm{E}_{\mathrm{a}}$ ) but which can confer high reproductive rates under advantageous circumstances, whereas tropical phytoplankton, in an aseasonal environment, are basically K-selected, with more efficient (low $E_{a}$ ) carboxylation but reduced ability to exploit environmental fluctuations (Margalef 1968). In terms of the capacity of these reactions, however, arctic phytoplankton are not obviously adapted to the cold, a result largely consistent with the findings of Clark $(1980,1983)$. The question of whether the high $E_{a}$ 's for RuBPC and photosynthesis result in higher levels of photosynthesis on an areal basis requires further study. Nevertheless, the information presented here will be of considerable significance for ecological modelling of the ocean in that it provides the appropriate factors for temperature dependence of photosynthesis and shows how the dependence varies with latitude.

If we were to adopt an alternative set of criteria for comparing the temperature responses of RuBPC and $\mathrm{P}_{\mathrm{m}}^{\mathrm{b}}$ for arctic and tropical phytoplankton, it would be possible to suggest a different interpretation of the results. Thus we might require that arctic RuBPC and $P_{m}^{b}$ be determined at tropical temperatures and vice versa, and that these 2 contrasts then be compared. We did not do these measurements, but Li (1985) has obtained such data for photosynthesis. He found that tropical temperatures were greatly supraoptimal for photosynthesis by arctic phytoplankton, rendering such a com- 
parison impractical. On the other hand, tropical phytoplankton photosynthesis at arctic temperatures was characterized by $E_{a}$ 's so high (e.g. $59 \mathrm{kcal} \mathrm{mole}^{-1}$ ) that their biological relevance was questionable. Such high values also indicate an inflection point in the Arrhenius plot and a sharp change in membrane lipid structure in response to low temperature (Raison 1980). Nevertheless, this result could be interpreted as meaning that arctic phytoplankton are adapted to the cold by having a lower $E_{a}$ for photosynthesis. Such an interpretation is not necessarily incompatible with that formulated above wherein we wished to compare the temperature response characteristics of the 2 groups of phytoplankton functioning near their respective ambient temperatures.

\section{LITERATURE CITED}

Bassham, J. A. (1971). The control of photosynthetic carbon metabolism. Science 172: 526-537

Berry, J. A., Raison, J. K. (1981). Responses of macrophytes to temperature. In: Lange, O. L., Nobel, P. S., Osmond, C. B., Ziegler, H. (ed.) Physiological plant ecology I. Responses to the physical environment. The encyclopedia of plant physiology, Vol, 12A, new ser. Springer, Berlin, p. $277-338$

Castellot, J. J. Jr., Miller, M. R., Lehtomaki, D. M., Pardee, A. B. (1979). Comparison of DNA replication and repair enzymology using permeabilized baby hamster kidney cells. J. biol. Chem. 254: 6904-6908

Clarke, A. (1980). A reappraisal of the concept of metabolic cold adaptation in polar marine invertebrates. Biol. J. Linnean. Soc. Lond. 44: 77-92

Clarke, A. (1983). Life in cold water: the physiological ecology of polar marine ectotherms. Oceanogr. mar. Biol. A. Rev. 21: 341-453

Eppley, R. W., Sharp, J. H., Renger, E. H., Perry, M. J., Harrison, W. G. (1977). Nitrogen assimilation by phytoplankton and other microorganisms in the surface waters of the central North Pacific Ocean. Mar. Biol. 39: 111-120

Foy, R. H. (1983). Interaction of temperature and light on the growth rates of two planktonic Oscillatoria species under a short photoperiod regime. Br. phycol. J. 18: 267-273

Gallegos, C. L., Platt, T. (1981). Photosynthesis measurements on natural populations of phytoplankton: numerical analysis. In: Platt, $\mathrm{I}$ (ed.) Physiological bases of phytoplankton ecology. Can. Bull. Fish. Aquat. Sci. 210: 103-112

Harrison, W. G., Platt, T., Irwin, B. (1982). Primary production and nutrient assimilation by natural phytoplankton populations of the eastern Canadian Arctic. Can. J. Fish. aquat. Sci. 39: 335-345

Herman, A. W., Mitchell, M. R., Young, S. W. (1984). A continuous pump sampler for profiling copepods and chlorophyll in the upper aceanic layers. Deep Sea Res. 31: $439-450$

Hochachka, P. W. Somero, G. N. (1971). Biochemical adaptation to the environment. In: Hoar, W. S., Randall, D. J. (ed.) Fish physiology, Vol. 6, Environmental relations and behavior. Academic Press, New York and London, p. 99-156
Hochachka, P. W., Somero, G. N. (1973). Strategies of biochemical adaptation. W. B. Saunders, Philadelphia

Holm-Hansen, O., Lorenzen, C. J., Holmes, R. W., Strickland, J. D. H. (1965). Fluorometric determination of chlorophyll. J. Cons. Int. Explor. Mer 30: 3-15

Horwitz, B. A., Hettinger, D. R. (1979). Cold-induced metabolic adjustments in ectotherms and homeotherms. In: Underwood, L. S. Tieszen, L. L., Callahan, A. B., Folk, G. E. (ed.) Comparative mechanisms of cold adaptation. Academic Press, New York, p. 91-127

Irwin, B., Platt, T., Harrison, W. G., Gallegos, C. L., Lindley, P. (1982). Phytoplankton productivity experiments and nutrient measurements in Ungava Bay, NWT, from August 1 to September 3, 1979. Can. Data Rept. Fish. Aquat. Sci. No. 287: 1-208

Irwin, B., Harris, L., Hodgson, M., Horne, E., Platt, T. (1983a). Primary productivity measurements in northern Foxe Basin, NWT, from 27 August to 7 September, 1981. Can. Data Rept. Fish. Aquat. Sci. No. 385: 1-40

Irwin, B., Harris, L., Dickie, P., Lindley, P., Platt, T. (1983b). Phytoplankton productivity in the eastern Canadian Arctic during July and August 1980. Can. Data Rept. Fish. Aquat. Sci. No. 386: 1-157

Irwin, B., Platt, T., Lindley, P., Fasham, M. J., Jones, K. (1983c). Phytoplankton productivity in the vicinity of a front, S.W. of the Azores during May 1981. Can. Data Rept. Fish. Aquat. Sci. No. 400: 1-101

Johnston, I. A., Goldspink, G. (1975). Thermodynamic activation parameters of fish myofibrillar ATPase enzyme and evolutionary adaptations to temperature. Nature, Lond. 257: $620-622$

Li, W. K. W. (1985). Photosynthetic response to temperature of marine phytoplankton along a latitudinal gradient $\left(16^{\circ} \mathrm{N}\right.$ to $74^{\circ} \mathrm{N}$ ). Deep Sea Res (in press)

Li, W K. W., Subba, Rao, D. V., Harrison, W. G., Smith, J. C., Cullen, J. J. Irwin, B., Platt T. (1983). Autotrophic picoplankton in the tropical ocean. Science 219: 292-295

Li, W. K. W., Smith, J. C., Platt, T. (1984). Temperature response of photosynthetic capacity and carboxylase activity in Arctic marine phytoplankton. Mar. Ecol. Prog. Ser. 17: $237-243$

Longhurst, A. R. (ed.) (1981). Biostat: an experiment in ocean plankton ecology. Cruise report for Hudson 81 (Panama to Puntarenas). Report Series BI-R-81-13, Bedford Institute of Oceanography, Dartmouth, Nova Scotia

Low, P. S., Bada, J. L., Somero, G. N. (1973). Temperature adaptation of enzymes: roles of the free energy, the enthalpy and the entropy of activation. Proc. natn. Acad. Sci. USA 70: 430-432

Margalef, R. (1968). Perspectives in ecological theory. Univ. of Chicago Press, Chicago

Miller, M. R., Castellot, J. J. Jr., Pardee, A. B. (1978). A permeable animal cell preparation for studying macromolecular synthesis. DNA synthesis and the role of deoxyribonucleotides in $\mathrm{S}$ phase initiation. Biochemistry, N. Y. $17:$ 1073-1080

Miller, M. R., Castellot, J. J. Jr., Pardee, A. B. (1979). A general method for permeabilizing monolayer and suspension cultured animals cells. Expl. Cell Res. 120: 421-425

Mukerji, D., Morris, 1. (1976). Photosynthetic carboxylating enzymes in Phaeodactylum tricornutum: assay methods and properties. Mar. Biol. 36: 199-206

Paerl, H. W. Tucker, J., Bland, P. T. (1983). Carotenoid enhancement and its role in maintaining blue-green algal (Microcystis aeruginosa) surface blooms. Limnol. Oceanogr. 28: $847-857$ 
Platt, T., Gallegos, C. L., Harrison, W. G. (1980). Photoinhibition of photosynthesis in natural assemblages of marine phytoplankton. J. mar. Res. 38: 687-701

Platt, T., Subba Rao, D. V., Irwin, B. (1983). Photosynthesis of picoplankton in the oligotrophic ocean. Nature, Lond. 301 702-704

Raison, J. K. (1980). Membrane lipids: structure and function. In: Stumpf, P. K. (ed.) The biochemistry of plants, a comprehensive treatise. Vol. 4, Lipids: structure and function. Academic Press, New York and London, p. 57-83

Sieburth, J. McN., Smetacek, V., Lenz, J. (1978). Pelagic ecosystem structure: heterotrophic compartments of the plankton and their relationship to plankton size fractions Limnol. Oceanogr. 23: 1256-1263

Smith, J. C., Platt, T., Harrison, W. G. (1983). Photoadaptation of carboxylating enzymes and photosynthesis during a spring bloom. Prog. Oceanogr. 12: 425-459

Smith, J. C., Platt, T., Li, W. K. W., Horne, E. P. W., Harrison,
W. G., Subba Rao, D. V., Irwin, B. D. (1985). Arctic marine photoautotrophic picoplankton. Mar. Ecol. Prog. Ser. 20: $207-220$

Storro, 1., McFadden, B. A. (1983). Ribulose bisphosphate carboxylase/oxygenase in toluene-permeabilized Rhodospirillum rubrum. Biochem. J. 212: 45-54

Syrett, P. J. (1973). Measurement of nitrate- and nitrite-reductase activities in whole cells of Chlorella. New Phytol. 72 : $37-46$

Tabita, F. R., Caruso, P., Whitman, W. (1978). Facile assay of enzymes unique to the Calvin cycle in intact cells, with special reference to ribulose 1,5 bisphosphate carboxylase. Analyt. Biochem. 84: 462-472

Whittenbury, R., Kelly, D. P. (1977). Autotrophy: a conceptual phoenix. Symp. Soc. gen. Microbiol. 27: 121-149

Yentsch, C. S., Menzel, D. W. (1963). A method for the determination of phytoplankton chlorophyll and phaeophytin by fluorescence. Deep Sea Res. 10: 221-231

This paper was submitted to the editor; it was accepted for printing on May 21, 1985 